\title{
Holocene hydroclimate reconstruction based on pollen, XRF, and grain-size analysis and its implications for past societies of the Korean Peninsula
}

\author{
Jinheum Park ${ }^{1}$, Jungjae Park ${ }^{1,2}$, Sangheon $\mathrm{Yi}^{3,4}$, Jaesoo Lim $^{3}$, Jin Cheul Kim ${ }^{3}$, Qiuhong Jin ${ }^{1}$, Jieun Choi ${ }^{1}$
}

$5 \quad{ }^{1}$ Department of Geography, Seoul National University, 1, Gwanak-ro, Gwanak-gu, Seoul, 08826, Republic of Korea

${ }^{2}$ Institute for Korean Regional Studies, Seoul National University, 1, Gwanak-ro, Gwanak-gu, Seoul, 08826, Republic of Korea

${ }^{3}$ Geology Division, Korea Institute of Geoscience and Mineral Resources, 124, Gwahak-ro, Yuseong-gu, Daejon, 34132, Republic of Korea

$10{ }^{4}$ Department of Petroleum Resources Technology, University of Science and Technology, 217, Gajeong-ro, Yuseong-gu, Daejeon, 34113, Republic of Korea

Correspondence to: Jungjae Park (jungjaep@snu.ac.kr) and Sangheon Yi (shyi@kigam.re.kr)

Abstract. The dynamics of the East Asian Summer Monsoon (EASM) and their link to past societies during the Holocene are topics of growing interest. In this study, we present analyses of a ca. 6,000-year pollen record, as well as X-ray

15 fluorescence (XRF) and grain-size data from the STP18-03 core sampled from Miryang in the Korean Peninsula, which spans ca. 8.3-2.3 ka BP. In-phase relationships of these proxies revealed an imprint of the Holocene Climate Optimum (HCO) during the early to mid-Holocene and subsequent drying toward the late Holocene in accordance with decreasing solar insolation. At centennial timescales, our study indicates wet conditions during ca. 8.3-7.5, 7.1-6.4, 6.0-4.8, and 3.6$2.8 \mathrm{ka} \mathrm{BP}$, and a drier climate during ca. 7.5-7.1, 6.4-6.0, and 4.8-3.6 ka BP. Notably, our finding for ca. 6.4-6.0 ka BP contributes further evidence of a drying event in the Korean Peninsula during this period. We suggest that the Pacific Ocean played a role in the underlying mechanism of hydroclimate change in the region. A strong Kuroshio Current (KC) and longterm El Niño-Southern Oscillation (ENSO)-like variability in the Western Tropical Pacific (WTP) were closely linked to the influence of the EASM over the Korean Peninsula. In particular, dry phases during ca. 4.8-3.6 and 2.8-2.3 ka BP, which were synchronous with a more active ENSO, closely corresponded to lower population levels according to a summed probability distribution (SPD) of archaeological records assembled in the Korean Peninsula. This finding implies that past human societies of Korea were highly vulnerable to climate deterioration caused by precipitation deficits.

\section{Introduction}

The East Asian Summer Monsoon (EASM) is part of the global monsoon system, and is a major driver of the East Asian Holocene climate (An, 2000; Dykoski et al., 2005; Ji et al., 2005; Wang et al., 2005; Chen et al., 2015a; Stebich et al., 2015).

30 The temporally and spatially complex nature of the EASM (An et al., 2000; Chen et al., 2015b; Zhou et al., 2016) requires further high-resolution studies from many different sites within the region to better reconstruct its impact throughout the 
https://doi.org/10.5194/cp-2020-98

Preprint. Discussion started: 7 August 2020

(c) Author(s) 2020. CC BY 4.0 License.

\section{(c) (i)}

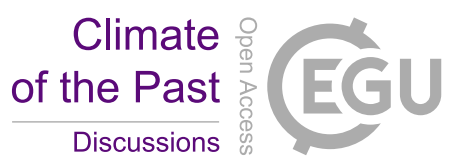

Holocene. For example, although many paleoclimate studies have focused on mainland China as a key region representing East Asia, site-specific and varying imprints of the EASM within the region are being increasingly addressed between the interior and coastal parts of China (Chen et al., 2015b; Zhou et al., 2016; Zhu et al., 2017) as well as between China and 35 Korea (Park et al., 2017). In the Korean Peninsula, the EASM has been suggested to be primarily driven by the Pacific Ocean, in processes such as the Kuroshio Current (KC) flowing from the Western Tropical Pacific (WTP) and the El NiñoSouthern Oscillation (ENSO) in the equatorial Pacific (Lim and Fujiki, 2011; Park et al., 2019; Park et al., 2016; Lee et al., 2020). Therefore, more high-resolution studies are needed to examine EASM dynamics closely in relation to oceanic forcing. However, despite increasing research efforts, high-resolution studies of the EASM in the Korean Peninsula remain scarce.

40 Although pollen analysis has been the most common approach to reconstruct past precipitation changes (Lim and Fujiki, 2011; Park et al., 2019; Lee et al., 2020; Park et al., 2016), this methodology contains physical limitations in enhancing the temporal resolution between samples. In contrast, speleothem-based Holocene EASM reconstructions, which permit finer resolution, have been confined to the last few thousand years in the Korean Peninsula and have not defined a clear link with the Pacific Ocean (Jo et al., 2017; Hong et al., 2012; Yu et al., 2016). Additionally, oxygen isotope values in speleothems sometimes do not purely reflect rainfall signals (Chen et al., 2015a; Maher and Thompson, 2012; Caley et al., 2014; Lachniet, 2009). Therefore, there is a significant need to assemble multiple types of proxies and maintain high temporal resolution for more accurate analysis of the link between the EASM and oceanic forcing.

Another topic of rising interest is the relationship between climate change and human societies. This issue has been addressed by many studies worldwide over the past few decades, in regions including Europe (Tallavaara et al., 2015; Büntgen et al., 2011), Greenland (D’Andrea et al., 2011), America (Munoz et al., 2010), Mesopotamia (Weiss et al., 1993; Carolin et al., 2019), India (Dixit et al., 2018), Egypt (Manning et al., 2017), and China (An et al., 2005; Xie et al., 2013; Wang et al., 2014). Most of these studies have supported a dominant climatic role in the vicissitudes of past societies, whereas others have recently reported human resilience to environmental stresses (Flohr et al., 2016; Blockley et al., 2018).

55 Thus, the relationship between climate and human societies is not always simplistically determined and may be case-specific. Even within sub-continents of China—e.g., Northwest, North, and South China, the Qinghai Tibetan Plateau—and Japan, human activity patterns during the Holocene appear to be distinct (Wang et al., 2014; Crema et al., 2016). It remains unclear whether this discrepancy reflects local differences in climate imprints or differences in societal responses to climate. Therefore, to analyze socio-environmental relationships in a particular area accurately, a direct comparison of continuous, 60 local, and high-resolution paleoclimate proxy data with human activity indicators is crucial. However, in the Korean Peninsula, this work remains in the nascent stage (Constantine et al., 2019; Park et al., 2019). The topic of climate-society relationships in Korea often depends on individual historical records of natural disasters, leading to assumptive storytelling about their potential impact on contemporary societal unrest (Cho, 2009). For older periods with scarce disaster records, qualitative and broad climate interpretations tend to be expressed as "warm/cold" or "wet/dry", often in comparison with 
https://doi.org/10.5194/cp-2020-98

Preprint. Discussion started: 7 August 2020

(c) Author(s) 2020. CC BY 4.0 License.

(c) (i)

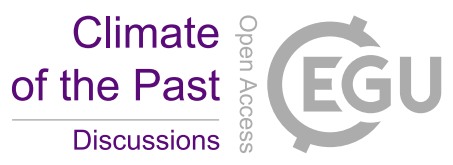

65 temporal and spatial patterns of archaeological findings (Ahn and Hwang, 2015), due to a lack of reliable high-resolution climate data.

Therefore, in the present study, we performed a multi-proxy analysis of Holocene hydroclimate change in the Miryang region of the Korean Peninsula from ca. 8.3 to $2.3 \mathrm{ka}$ BP. We combined pollen, X-ray fluorescence (XRF), and grain-size data to reconstruct the EASM history over the Korean Peninsula. The high temporal resolution of our XRF analysis allowed us to analyze the paleoclimate dataset at decadal to annual scales. We examined the role of the Pacific Ocean as an underlying mechanism for EASM history in the Korean Peninsula, particularly in terms of ENSO variance and heat and moisture supply along the KC. We also identified a synchronous change between hydroclimate and past population in the Korean Peninsula and explored the processes through which past human societies may have responded to climate impacts during the Holocene.

\section{Regional Setting}

Our coring site $\left(35^{\circ} 26^{\prime} 18.84^{\prime \prime} \mathrm{N}, 128^{\circ} 46^{\prime} 41.26^{\prime \prime} \mathrm{E}\right.$; $4.64 \mathrm{~m}$ a.s.1.) is located in a floodplain of the Miryang River in the southeastern part of the Korean Peninsula (Fig. 1a-c). The Miryang River is a tributary of the Nakdong River, which eventually flows out to the Korea Strait, between the Korean Peninsula and the Japanese Archipelago. The backdrop of the coring site is a group of small mountains several hundred meters in elevation, including Jongnamsan (663 m) and Palbongsan (391 m) (Fig. 1c). The Korean Peninsula is situated amid the East Asian monsoonal system, and experiences seasonal differences in air pressure due to its location between the Eurasia continent and the Pacific Ocean (An, 2000) (Fig. 1a). In summer, hot and humid southeasterly wind flows into the Korean Peninsula under the influence of the warm KC, whereas in winter, cold and dry northwesterly wind from the Siberian High dominates. According to a 30-year (1981-2010

$85 \mathrm{AD})$ climate record from a meteorological observation station $6 \mathrm{~km}$ north of the coring site, the mean annual temperature is $13.3{ }^{\circ} \mathrm{C}$, with a January minimum of $0.0^{\circ} \mathrm{C}$ and August maximum of $25.8^{\circ} \mathrm{C}$. The mean annual precipitation is $1229.4 \mathrm{~mm}$; precipitation is lowest in December $(16.4 \mathrm{~mm})$ and highest in July $(269.5 \mathrm{~mm})$ (Fig. 1d). A total precipitation of $829.5 \mathrm{~mm}$ during June-September, JJAS) accounts for $67.5 \%$ of the total annual precipitation, indicating significant influence of the EASM on the hydroclimate of the region (Korea Meteorological Administration, 2020).

90

The regional vegetation of Miryang is composed of temperate broadleaf and mixed forest. On Mt Jongnamsan, arboreal species such as Pinus densiflora, Quercus serrata, Rhus sylvestris, Q. acutissima, Castanea crenata, Indigofera kirilowii, and $Q$. variabilis and herb species such as Oplismenus undulatifolius, Carex lanceolata, Artemisia keiskeana, Spodiopogon sibiricus, Cocculus trilobus, and Arundinella hirta dominate at 30-298 m altitude (Korea National Insitute of Ecology, 2016).

95 In wetlands along the Miryang River, Phragmites communis, Salix gracilistyla, Phragmites japonica, Persicaria longiseta, 
https://doi.org/10.5194/cp-2020-98

Preprint. Discussion started: 7 August 2020

(c) Author(s) 2020. CC BY 4.0 License.

(c) (i)

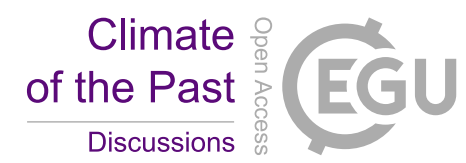

Persicaria thunbergii, Juncus effuses var. decipiens, and Zizania latifolia are also found (Ministry of Environment of the Republic of Korea, 2002).

\section{Materials and Methods}

\subsection{Core materials and dating}

100 In April 2018, the 20-m STP18-03 core was collected in 1-m sections from a floodplain of the Miryang River (Fig. 1). Depth zones of the uppermost $0-1.25 \mathrm{~m}$ and lowermost $14-20 \mathrm{~m}$ were excluded from all analyses as the former were regarded to have been affected by human activities and the latter consisted mainly of gravel. We sent a total of 16 samples to the Korea Institute of Geoscience and Mineral Resources (KIGAM), Republic of Korea (Table 1) for age dating; eight were measured using the optically stimulated luminescence (OSL) dating method. These samples were treated with $\mathrm{Na}_{4} \mathrm{P}_{2} \mathrm{O}_{7}, \mathrm{HCl}_{2} \mathrm{H}_{2} \mathrm{O}_{2}$,

105 and $\mathrm{H}_{2} \mathrm{SiF}_{6}$ to extract quartz with a diameter of 4-11 $\mu \mathrm{m}$. Then, OSL signals were measured using a TL-DA-20 reader (Ris $\emptyset$ DTU, Roskilde, Denmark) equipped with a blue light-emitting diode (LED; $470 \pm 20 \mathrm{~nm}$ ) stimulation source. Plant fragments from the other eight samples were used for radiocarbon dating by accelerator mass spectrometry. Based on the results, we constructed an age model using the bacon ver. $2.3 \mathrm{R}$ package (Blaauw and Christen, 2011) with the IntCal13 calibration dataset (Reimer et al., 2013) (Fig. 2b). Two radiocarbon dates from depths of $795 \mathrm{~cm}$ and $1032 \mathrm{~cm}$ were omitted due to their anomalous ages in relation to those of other samples.

\subsection{Proxy Analyses}

We performed palynological analysis of a total of 137 samples at intervals ranging from 1 to $70 \mathrm{~cm}(1-6 \mathrm{~cm}$ for sections from 395 to $1010 \mathrm{~cm}$ and $9-70 \mathrm{~cm}$ for the remaining sections). The average temporal resolution was 41.4 years, with minimum and maximum values of 12 and 348 years, respectively. For sample preparation, we followed the standard protocol

115 of Faegri et al. (1989) including $\mathrm{HCl}(10 \%), \mathrm{KOH}(10 \%), \mathrm{HF}(40 \%)$, and acetolysis. $\mathrm{KOH}$ treatment was repeated twice to remove organic matter completely. For highly humic samples in the range of 501-528 cm, the KOH procedure was repeated up to three times. For each sample, one lycopodium tablet containing 177,745 spores was added, and at least 300 pollen grains and spores were counted on each slide using a Leica microscope at $400 \times$ magnification. For palynomorph identification, we referred to a pollen atlas from Lake Suigetsu, Japan (Demske et al., 2013). The percentage of pollen was calculated for each taxon relative to the total sum of non-aquatic pollen grains and spores in the sample. The result was visualized using the Tilia software ver. 2.0.41 (Grimm, 1991), and stratigraphically constrained cluster analysis was conducted using CONISS (Grimm, 1987) based on non-aquatic taxa.

Grain-size analysis was performed using a Mastersizer 2000 laser diffraction particle-size analyzer (Malvern Instruments,

125 UK) at KIGAM. Approximately $300 \mathrm{mg}$ of each sample was collected at 10-cm intervals from the $205-1390 \mathrm{~cm}$ section. These subsamples were treated with $\mathrm{H}_{2} \mathrm{O}_{2}(35 \%)$ and $\mathrm{HCl}(1 \mathrm{~N})$ to remove organic matter and carbonates. Grain sizes of $<4$ 
$\mu \mathrm{m}, 4-63 \mu \mathrm{m}$, and $>63 \mu \mathrm{m}$ were classified as clay, silt, and sand, respectively. XRF analysis was also conducted at KIGAM using an XRF core scanner (Avaatech B.V.; Alkmaar, Netherlands), which extracts elemental concentration data in a nearly continuous manner (Croudace et al., 2006; Löwemark et al., 2011). XRF signals were measured from split core surfaces from depths of $12.5-1293.5 \mathrm{~cm}$, with settings of $10 / 50 \mathrm{kV}$ and $0.25 / 1.0 \mathrm{~mA}$, and a sampling time of $30 \mathrm{~s}$. In total, 2,088 values were collected at a resolution of $0.5 \mathrm{~cm}$. However, we did not perform paleoenvironmental interpretations on data at depths above $365 \mathrm{~cm}$, because these sections correspond to periods later than ca. $2.3 \mathrm{ka} \mathrm{BP}$, for which there is evidence of agriculture in the Miryang region (Yoon et al., 2005)

135 Cross-spectral analysis on the proxy data was conducted using the REDFIT-X software ver. 1.1 (Ólafsdóttir et al., 2016) with 1,000 Monte Carlo simulations (nsim = 1000), an oversampling value of 4.0 for Lomb-Scargle Fourier transform (ofac $=4.0$ ), four segments with $50 \%$ overlap $(\mathrm{n} 50=4)$, and a Welch window (iwin $=1)$. To avoid statistical bias, we eliminated two pollen values at depths of 380 and $395 \mathrm{~cm}$, which reflected an abrupt shift immediately before cessation of pollen deposition. For all other proxies, we used only values that were within the timespan of the pollen data for analysis.

\section{$140 \quad 4$ Results}

\subsection{Chronology}

The chronology of the STP18-03 core contained a record of ca. 6420 years, from the mid- to late Holocene, representing the period from ca. $8340 \mathrm{cal} \mathrm{yr} \mathrm{BP} \mathrm{(1280} \mathrm{cm} \mathrm{depth)} \mathrm{to} \mathrm{ca.} 1920 \mathrm{cal}$ yr BP (350 cm depth) (Fig. 2b). The sedimentation rate was $0.38 \mathrm{~cm}$ per year for the $790-1280-\mathrm{cm}$ segment and $0.09 \mathrm{~cm}$ per year for the 380-790-cm segment (average, $0.14 \mathrm{~cm}$ per

145 year). Sedimentation was continuous throughout the core, except for the 901-905 and 1100-1140-cm segments, perhaps due to on-site technical problems while coring or disturbance by underground water.

\subsection{Stratigraphy and multi-proxy environmental data}

\subsubsection{Zone $1(790-1390 \mathrm{~cm})$}

This zone consists mainly of dark brown clay, although sand is frequently observed in multiple layers (Fig. 2a). Sand percentages fluctuate significantly between $0.5 \%$ and $79.1 \%$ (Fig. 2c). The amount of titanium (Ti) also varies, with a large amplitude generally in the opposite direction to that of sand content (Fig. 2d). The tree pollen percentage is generally low at 1145-1280 cm, with a minimum value of $77.2 \%$ (Fig. 2e). Artemisia (mugwort), Poaceae (wild grass), and fern species comprise $20.6 \%$ of the pollen composition (Fig. 2f); this trend is reversed at 790-1090 cm, where the proportion of arboreal pollen remains high and stable at 87.1-96.4\%, and that of Artemisia and Poaceae pollen together with fern spores remains

155 low, at an average of $8.7 \%$. The largest proportion of arboreal pollen is constituted by Quercus (oak) (Fig. 3); other broadleaf tree genera include Alnus (alder), Fraxinus (ash), and Ulmus (elm), which reach the highest proportion in this zone 
of the core. Notably, at a depth of $950 \mathrm{~cm}$, a sudden increase in Alnus pollen to $58.0 \%$ (Fig. 3) coincides with abrupt shifts in sand and Ti content (Fig. 2c and d). This abnormal value implies a sudden local disturbance event that perturbed the preexisting vegetation and gave rise to pioneer species with high environmental tolerance (McVean, 1953; Weng et al., 2004).

\subsubsection{Zone $2(400-790 \mathrm{~cm})$}

From 790 to $400 \mathrm{~cm}$, the clay content gradually increases as depth decreases, and the colour changes from light brown to grey (Fig. 2a). Sand percentages and Ti content stabilize, changing in tandem with the pollen data (Fig. 2c-e). Overall, lower sand content is concurrent with a lower proportion of tree pollen and higher Ti values, and vice versa. Between 590 and 635 $\mathrm{cm}$, where the sand percentage temporarily decreases to $28.8 \%$, the Ti content increases sharply as the proportion of tree pollen drops to as low as $83.1 \%$ due to a decline in the main arboreal genera such as Quercus, Pinus, Alnus, Fraxinus, and Ulmus (Fig. 3). A similar trend is also observed between 420 and $500 \mathrm{~cm}$, where the proportions of sand and arboreal pollen drop to below $10 \%$ and $80 \%$, respectively. Upland herbs such as Artemisia and Poaceae occupy this relatively open area, whereas Pteridium ferns rise to a maximum value in this zone. This trend is in contrast with the 500-590 and 635-790 cm sections, in which the proportions of sand and tree pollen remain high as Ti XRF values are low. Notably, a high proportion of tree pollen at 500-590 cm is led by a climax in Quercus pollen (Fig. 3).

\subsubsection{Zone $3(210-400 \mathrm{~cm})$}

This part of the core is characterized by brown clayey silt (Fig. 2a) with low sand content (Fig. 2c) and high Ti values (Fig. 2d). Pollen deposition is interrupted after an explosive increase in upland herbs (mainly Artemisia and Poaceae), Cyperaceae (sedges), and Polypodiales undiff. ferns at the beginning of this zone (Figs. 2e, f and 3). Considering the near absence of

175 sand content in this zone (Fig. 2c), this disruption may have been caused by a cessation of water supply from the river to the floodplain due to either climate drying or river route alteration, and the subsequent exposure of the site to air.

\section{Discussion}

\subsection{Role of our proxy data as paleoclimate indicators}

At millennial timescales, our $\mathrm{Ti}$, pollen, and sand content data are consistent with a declining trend of summer solar insolation in the Northern Hemisphere from the mid- to late Holocene (Berger and Loutre, 1991) (Fig. 4a-e). The gradual decrease in the proportion of arboreal pollen (Fig. 4c) reflects cooling and drying associated with a southward migration of the Intertropical Convergence Zone (ITCZ) induced by orbital forcing (Berger and Loutre, 1991; Haug et al., 2001). Our sand proportion data also follow this trend, as fluvial sand discharge by the Miryang River would have weakened due to less precipitation in the late Holocene relative to earlier periods (Fig. 4e). Ti XRF values, in the opposite direction, change in tandem with these two proxies, such that the signal generally increases towards the late Holocene (Fig. $4 \mathrm{~b}$ ). In many studies, Ti has been used as an indicator of terrestrial erosion, although its paleoenvironmental interpretation may vary according to 
regional context (Sun et al., 2008; Bakke et al., 2009). In the present study, considering its synchronicity with arboreal pollen proportion (Fig. 4b and c), we interpret Ti as reflecting hydroclimate change in the Korean Peninsula. During wet periods, more tree growth (mainly oak and pine trees, Fig. 3) in nearby hills would have suppressed soil erosion via the anchoring effect of roots, leading to lower Ti XRF values. However, as climate became drier towards the late Holocene, tree replacement by herbs and ferns would have weakened this effect, resulting in greater Ti erosion.

This attribute of Ti data as a climate proxy in relation to vegetation change is further supported by cross-spectral analysis (Ólafsdóttir et al., 2016) (Fig. 5). The analysis of Ti and arboreal pollen data implies high coherency at frequencies of 518, 148, 127, and 104 years (Fig. 5a). A 500-year frequency is widely detected in East Asian monsoonal regions and has been attributed to oceanic influences such as thermohaline circulation (THC) or the ENSO, possibly modulated by solar activity (Roth and Reijmer, 2005; Dima and Lohmann, 2009; Xu et al., 2014; Xu et al., 2019; Stebich et al., 2015; Park et al., 2019). This link is corroborated by additional analysis with the WTP SST record from the MD98-2176 core (Stott et al., 2004) and hematite-stained grains (HSG) in the North Atlantic (Bond et al., 2001), which commonly show the $~ 500$-year frequency observed in our Ti values and in the tree pollen data (Fig. 5b-c and e-f). Smaller frequencies of $\sim 150, \sim 130$, and $\sim 100$ years are likely attributable to a solar origin (Scuderi, 1993; Roth and Reijmer, 2005); these signals have been interpreted in terms of solar modulation on the EASM strength at Qinghai Lake, central China (Ji et al., 2005) and Jeju Island (Park et al., 2017), south of the Korean Peninsula (Fig. 1a and b). Our additional analysis of total solar irradiation (TSI) data (Steinhilber et al., 2009) contributes further evidence of a solar contribution to these cycles (Fig. 5d and g), although $\sim 130$ - and $\sim 100$-year frequencies fail to reach statistically significant levels between tree proportion and TSI (Fig. 5g), possibly due to the lower temporal resolution of pollen analysis relative to XRF scanning.

\subsection{Climate change in the Korean Peninsula during the Holocene}

From ca. 8.3 to 5.4 ka BP, highly sustained proportions of arboreal pollen (Fig. 4c) likely reflect the influence of the Holocene Climate Optimum (HCO) (An et al., 2000; Wanner et al., 2008; Zhou et al., 2016), which resulted in warmer summers in the Korean Peninsula, possibly increasing annual average temperatures by $1-2{ }^{\circ} \mathrm{C}$ compared with the preindustrial period (Renssen et al., 2012). The climate was generally warm and humid, influenced by the northward advance of the EASM (Yang et al., 2015). However, one exception is an abrupt drop in the proportion of tree pollen at ca. 8.2 ka BP, when pollen from herb taxa including mugwort (Artemisia) and wild grass (Poaceae) suddenly increased (Fig. 3), reflecting the "8.2 ka event", an abrupt global cooling phenomenon (Alley et al., 1997; Veski et al., 2004; Cheng et al., 2009), which corroborates our previous reports of this event in the Korean Peninsula (Park et al., 2018; Park et al., 2019).

At centennial timescales, several periods of wet and dry climate alternate throughout the mid- to late Holocene. Our Ti, pollen, and sand data indicate relatively wet climates for ca. 8.3-7.5, 7.1-6.4, 6.0-4.8, and 3.6-2.8 ka BP, and drier conditions for ca. 7.5-7.1, 6.4-6.0, and 4.8-3.6 ka BP (Fig. 4b-e). A pronounced feature of this multi-centennial-scale 
https://doi.org/10.5194/cp-2020-98

Preprint. Discussion started: 7 August 2020

(c) Author(s) 2020. CC BY 4.0 License.

\section{(c) (i)}

environmental change is a close connection with SST records from the Pacific Ocean (Sun et al., 2005; Stott et al., 2004)

(Fig. $4 \mathrm{f}$ and g). Periods of warm and wet climate are accompanied by high SST records obtained for the Okinawa Trough (Fig. 4f), which is located directly on the path of the KC (Fig. 1a), which is an important contributor to EASM strength in coastal East Asia, where it is a major transport mechanism of heat and moisture from the WTP (Jian et al., 2000; Zhou et al., 2009; Lim and Fujiki, 2011; Hu et al., 2015; Park et al., 2016; Constantine et al., 2019; Lee et al., 2020). During ca. 8.3-7.5, 7.1-6.4, 6.0-4.8, and 3.6-2.8 ka BP, greater heat and water vapor supply along the KC would have enabled active atmospheric convection and stronger EASM influence over the Korean Peninsula, whereas the opposite would have occurred during ca. 7.5-7.1, 6.4-6.0, and 4.8-3.6 ka BP.

Among these periods, a sign of drying and/or cooling around 6.4-6.0 ka BP (Fig. 4b-e) is consistent with previous findings at Lake Pomaeho in the central Korean Peninsula (Constantine et al., 2019) (Fig. 1b). This drying signal may have been muted in our previous study of Gwangyang (Park et al., 2019) (Fig. 1b, GY-1) due to lower temporal resolution ( 80 years) around the sedimentary section. However, evidence of climate deterioration during 6.4-6.0 ka BP is not consistent across different regions of East Asia. For example, Daihai Lake (Xiao et al., 2004) and Gonghai Lake (Chen et al., 2015a) in North China and Dongge Cave in South China (Wang et al., 2005) (Fig. 1a) record abrupt shifts toward less precipitation. However, in Lake Xiaolongwan (Chu et al., 2014; Xu et al., 2019) and Lake Sihailongwan (Stebich et al., 2015) in Northeast China (Fig. 1a), this signal is not clear. Although this discrepancy may reflect regionally different climate patterns, we cannot rule out the possibility of inherent bias in the proxy-based reconstructions. For example, although the DA stalagmite in Dongge Cave (Wang et al., 2005) (Fig. 1) recorded significant drying around 6.4-6.0 ka BP, the D4 stalagmite (Dykoski et al., 2005), which was obtained from the same cave, does not exhibit clear changes. The reliability of EASM precipitation signals among Chinese stalagmites has been questioned due to mixed effects of the Indian Summer Monsoon (Fig. 1a, ISM) and/or hydrologic processes affecting oxygen isotope values (Maher and Thompson, 2012; Chen et al., 2015a; Caley et al., 2014). Likewise, in pollen records, source area and/or overestimation issues inherent in palynological methodology (Seppä and Bennett, 2003) can lead to potential bias in blurring climate signals. In this study, we suspect that a methodological issue explains the smaller amplitude of the changes in pollen proportions during ca. 7.5-7.1 ka BP, whereas the other sedimentary proxies, XRF and sand percentage data exhibit clearer phase shifts with the Pacific Ocean (Fig. 4b-g). Similarly, in pollen records from Daihai Lake (Xiao et al., 2004) and Gonghai Lake (Chen et al., 2015a), drying signals during ca. 7.5-7.1 ka BP are less evident than those during ca. 6.4-6.0 ka BP. Considering this complexity among different sites and time periods, imprints of EASM weakening during ca. 7.5-7.1 and 6.4-6.0 ka BP are not yet clearly explicable at the regional scale in East Asia and therefore require further research with abundant high-resolution data across different study sites.

Our proxy data also indicate a pronounced drying trend in the Korean Peninsula during ca. 4.8-3.6 ka BP (Fig. 4b-e), which is consistent with global findings of significantly decreased precipitation and/or temperature around this period (Bond et al., 1997; Wang et al., 2005; Wanner et al., 2011; Bond et al., 2001). In East Asia, this climate impact may have been amplified 
https://doi.org/10.5194/cp-2020-98

Preprint. Discussion started: 7 August 2020

(c) Author(s) 2020. CC BY 4.0 License.

\section{(c) (i)}

by long-term ENSO-like variance, which strengthened from the mid-Holocene (Moy et al., 2002; Conroy et al., 2008;

Donders et al., 2008). The ENSO possibly exerts a dampening effect on EASM intensity by affecting low- to mid-latitude atmospheric patterns (Xu et al., 2019; Feng and Hu, 2014; Hu et al., 2015), evidence of which has been found in coastal East Asian regions, particularly during El Niño-like phases (Chen et al., 2015b; Park et al., 2017; Park et al., 2016). Active ENSO-like forcing would frequently have pushed warm seawater pools in the western Pacific farther to the east (Timmermann et al., 2018), consequently lowering WTP SST values (Fig. 4g) and weakening the KC (Hu et al., 2015) (Fig. $4 f)$.

\subsection{Response of past societies to mid- to late Holocene climate change}

From ca. 6 ka BP to $2.3 \mathrm{ka}$ BP, the Ti value of the STP18-03 core closely follows the summed probability distribution (SPD) plots of radiocarbon dates collected from archaeological samples in the Korean Peninsula (Oh et al., 2017) (Fig. 6a). The SPD method is increasingly used as a proxy for past population levels (Wang et al., 2014; Ahn and Hwang, 2015; Tallavaara et al., 2015; Crema et al., 2016; Bevan et al., 2017; Oh et al., 2017; Xu et al., 2019) by assembling radiocarbon age calculations from archaeological findings (Gamble et al., 2005; Surovell et al., 2009). In our data, Ti content gradually decreased and remained low until ca. $4.8 \mathrm{ka} \mathrm{BP}$, recovered high values by ca $3.6 \mathrm{ka} \mathrm{BP}$, and then diminished again before increasing at ca. $2.8 \mathrm{ka} \mathrm{BP}$ (Fig. 6b). This trend is coherent with, but opposite to, changes in the SPD data, which indicate larger populations during ca. 6.0-4.8 ka BP and ca. 3.6-2.8 ka BP, and lower populations during ca. 4.8-3.6 ka BP and after ca. $2.8 \mathrm{ka} \mathrm{BP}$ (Fig. 6a). Three abrupt transition points around 4.8, 4.2, and $4.0 \mathrm{ka} \mathrm{BP}$ are found in both datasets, validating their link (Fig. 6a and b). Together with our previous research (Constantine et al., 2019; Park et al., 2019), this robust synchronicity between $\mathrm{Ti}$ data and archaeological records contributes to accumulating evidence that past societies of the Korean Peninsula responded strongly and with great sensitivity to climate change.

Given its synchronicity with arboreal pollen data, we used the Ti XRF signal as a proxy of climate change and identified two periods with a relatively warm and wet climate, when past populations increased: ca. 6-4.8 ka BP and ca. 3.6-2.8 ka BP (Fig. 6). This link is accompanied by high SSTs in the Okinawa Trough (Fig. 4f). Notably, the former period corresponds to the latter part of the HCO, characterized by a warm and wet climate during the mid-Holocene both globally (Wanner et al., 2008; Renssen et al., 2012; Renssen et al., 2009) and in the Korean Peninsula (Park et al., 2019). During this period, favorable climate conditions would have enabled successful hunting and gathering, with sufficiently abundant food resources to sustain population growth (Wang et al., 2014). Besides hunting and gathering, evidence of foxtail, broomcorn, and legume cultivation has been found at Korean Middle-Late Chulmun (Neolithic) sites for as early as ca. 5.5 ka BP (Lee, 2011). Although the degree to which farming was an important food source for the Chulmun people remains unclear, it is likely that a warm and humid climate provided better conditions for successful agriculture (Wang et al., 2014; Xu et al., 2019).

285 Moreover, the latter period of ca. 3.6-2.8 ka BP was a time of explosive increase in Bronze Age settlements in the Korean Peninsula, beginning as early as ca. $3.9 \mathrm{ka} \mathrm{BP}$ (Kim and Bae, 2010). Similarly, Lee (2011) suggested a major transition from 
https://doi.org/10.5194/cp-2020-98

Preprint. Discussion started: 7 August 2020

(c) Author(s) 2020. CC BY 4.0 License.

\section{(c) (i)}

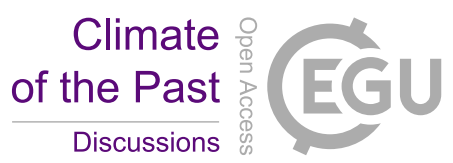

Chulmun to Mulmun (Bronze) culture in the Korean Peninsula at ca. 3.4 ka BP, with clear evidence of intensive agriculture, including domesticated plants such as rice. The impact of temporary climate deterioration around $3.2 \mathrm{ka}$ BP (Fig. 6b-d), which may reflect enhanced ENSO activity (Moy et al., 2002) (Fig. 6e) and/or the 3.2-ka event (Kaniewski et al., 2017), was not large enough in the Korean Peninsula to interrupt the increasing population trend during this cultural boom (Fig. 6a).

During ca. 4.8-3.6 ka BP, high Ti values and a low proportion of arboreal pollen indicate a cool and dry climate in the Korean Peninsula when human activity declined (Fig. 6). Evidence of significant cooling and drying events around this period (Bond et al., 1997; Wang et al., 2005; Wanner et al., 2011; Bond et al., 2001) and their potential impacts on the shrinkage or unrest of past societies (DeMenocal, 2001) have been widely reported from various sites worldwide including Mesopotamia (Weiss et al., 1993; Carolin et al., 2019), India (Dixit et al., 2018; Dixit et al., 2014), China (An et al., 2005; Li et al., 2018; Xiao et al., 2018; Xu et al., 2019), Japan (Kajita et al., 2020; Kawahata et al., 2009), and Korea (Constantine et al., 2019; Park et al., 2019). In these periods, climate drying would have increased dietary stress by hindering successful hunting, gathering, millet cultivation and even livestock domestication (Roffet-Salque et al., 2018; Kawahata et al., 2009).

300 Abrupt and synchronous changes in Ti and pollen data together with the decline in archaeological SPD values at ca. 4.8, 4.2, and 4.0 ka BP imply a significant impact of sudden climate deterioration on Korean prehistoric societies (Fig. 6). These changes were likely triggered by the onset of an active ENSO at ca. $4.8 \mathrm{ka}$ BP (Fig. 6e) and modulated by lower SSTs in the Okinawa Trough and WTP until ca. 3.6 ka BP (Fig. 6f).

Our Ti XRF data suggest synchronicity of climate deterioration with a decline in population in the Korean Peninsula from ca. 2.8 ka BP until ca. 2.3 ka BP (Fig. 6a-d). During this period, SSTs in the Okinawa Trough and WTP decreased (Fig. 4f and g), and ENSO activity around $2.7 \mathrm{ka}$ BP (Fig. 6e) may have amplified the climate impact. Although no palynological record is available for this period (Fig. 3 and 6c), our previous study of Gwangyang (Park et al., 2019) (Fig. 1b, GY-1) supports this socio-environmental link (Fig. 6d). In the Korean Peninsula, most Bronze Age pottery disappears during this period, as observed for Misa-ri, Garak-dong, and Heunam-ri-type pottery around 2.9-2.8 ka BP and Yeoksam-dong, Songguk-ri, and Geomdan-ri-type pottery during 2.8-2.4 ka BP (Lee, 2017; Ahn and Hwang, 2015). In this sense, it is likely that decreasing SPD values after ca. $2.8 \mathrm{ka}$ BP (Fig. 6a) primarily reflect a collapse of Bronze Age culture in Korea, and that this change was influenced by climate drying and/or cooling at that time (Fig. 6b-d). As during ca. 4.8-3.6 ka BP, the population decline after ca. $2.8 \mathrm{ka}$ BP was a widespread phenomenon that has been detected in Korea and at many sites worldwide including mainland China (Wang et al., 2014), Turkey (Woodbridge et al., 2019), and Britain and Ireland (Bevan et al., 2017). Therefore, climate impact on human societies during this period should be understood within a global context, possibly in connection with a cooling trend after the Bond event 2 (Bond et al., 1997; Wanner et al., 2011). 
https://doi.org/10.5194/cp-2020-98

Preprint. Discussion started: 7 August 2020

(c) Author(s) 2020. CC BY 4.0 License.

(c) (i)

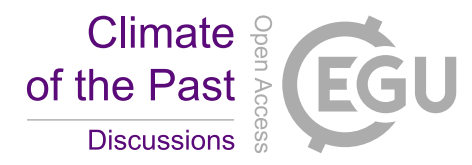

\section{Conclusion}

Our multi-proxy analysis of pollen, XRF, and grain-size data was used to reconstruct the EASM history of the Korean

Peninsula from ca. 8.3 to $2.3 \mathrm{ka}$ BP. We identified a concurrent change between hydroclimate and past human activity. The Holocene climate in Korea was sensitively modulated by the strength of the KC and ENSO-like variance. Wet conditions prevailed during ca. 8.3-7.5, 7.1-6.4, 6.0-4.8, and 3.6-2.8 ka BP, when SSTs in the western Pacific Ocean were sufficiently high to enhance EASM strength. However, during ca. 7.5-7.1, 6.4-6.0, and 4.8-3.6 ka BP, climate became drier due to KC weakening and an increase in ENSO-like variance that likely dampened the EASM. Although regional imprints of climate deterioration during ca. 6.4-6.0 ka BP remain unclear in East Asia, the findings of our study contribute to our knowledge of this climate event in the Korean Peninsula. The reconstructed hydroclimate change was also synchronous with past population levels inferred by the SPD of archaeological remains. Past societies flourished amid favorable climate conditions during ca. 6-4.8 ka BP and ca. 3.6-2.8 ka BP, but suffered from precipitation deficits during ca. 4.8-3.6 ka BP. This finding is consistent with multiple findings of contemporary collapses of past civilizations worldwide and confirms that this global socio-environmental link was present in the Korean Peninsula. Nevertheless, it should be noted that the relationship between climate and past societies is not always straightforward. Further research is required to elaborate our understanding of its dynamics.

\section{Data availability}

Data used in this study are available from Jinheum Park (jinheum94@snu.ac.kr) or Jungjae Park (jungjaep@snu.ac.kr) on reasonable request. The data are also available at the open-access repository Pangaea.de (DOI not provided yet).

\section{Author contribution}

Jinheum Park: Conceptualization, Formal analysis, Investigation, Writing - Original Draft, Visualization. Jungjae Park: Conceptualization, Methodology, Writing - Review \& Editing, Supervision, Project administration, Funding acquisition. Sangheon Yi: Methodology, Resources, Project administration. Jaesoo Lim: Investigation. Jin Cheul Kim: Investigation.

Quihong Jin: Investigation. Jieun Choi: Investigation

\section{Competing interests}

The authors declare that they have no conflict of interest. 
https://doi.org/10.5194/cp-2020-98

Preprint. Discussion started: 7 August 2020

(c) Author(s) 2020. CC BY 4.0 License.

(c) (i)

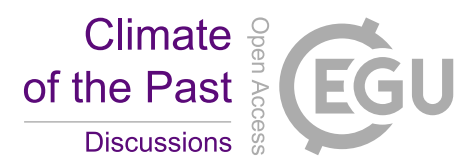

\section{Acknowledgements}

This work was supported by the Basic Research Project (GP2017-013) of the Korea Institute of Geoscience and Mineral

Resources (KIGAM), the National Research Foundation of Korea (NRF-2018S1A2A01025813), and the Hanmaum Peace and Research Foundation (HPRF). We thank the editor and anonymous reviewers for their useful comments and suggestions for improving the manuscript.

\section{References}

Ahn, S.-M., and Hwang, J. H.: Temporal fluctuation of human occupation during the 7th-3rd millennium cal BP in the central-western Korean Peninsula, Quatern. Int., 384, 28-36, 2015.

Alley, R. B., Mayewski, P. A., Sowers, T., Stuiver, M., Taylor, K. C., and Clark, P. U.: Holocene climatic instability: A prominent, widespread event 8200 yr ago, Geology, 25, 483-486, 1997.

An, C.-B., Tang, L., Barton, L., and Chen, F.-H.: Climate change and cultural response around 4000 cal yr BP in the western part of Chinese Loess Plateau, Quaternary Res., 63, 347-352, 2005.

355 An, Z.: The history and variability of the East Asian paleomonsoon climate, Quaternary Sci. Rev., 19, 171-187, 2000.

An, Z., Porter, S. C., Kutzbach, J. E., Xihao, W., Suming, W., Xiaodong, L., Xiaoqiang, L., and Weijian, Z.: Asynchronous Holocene optimum of the East Asian monsoon, Quaternary Sci. Rev., 19, 743-762, 2000.

Bakke, J., Lie, Ø., Heegaard, E., Dokken, T., Haug, G. H., Birks, H. H., Dulski, P., and Nilsen, T.: Rapid oceanic and atmospheric changes during the Younger Dryas cold period, Nat. Geosci., 2, 202-205, 2009.

360 Berger, A., and Loutre, M.-F.: Insolation values for the climate of the last 10 million years, Quaternary Sci. Rev., 10, 297 $317,1991$.

Bevan, A., Colledge, S., Fuller, D., Fyfe, R., Shennan, S., and Stevens, C.: Holocene fluctuations in human population demonstrate repeated links to food production and climate, P. Natl. Acad. Sci. USA, 114, E10524-E10531, 2017.

Blaauw, M., and Christen, J. A.: Flexible paleoclimate age-depth models using an autoregressive gamma process, Bayesian 365 Anal., 6, 457-474, 2011.

Blockley, S., Candy, I., Matthews, I., Langdon, P., Langdon, C., Palmer, A., Lincoln, P., Abrook, A., Taylor, B., and Conneller, C.: The resilience of postglacial hunter-gatherers to abrupt climate change, Nature ecology \& evolution, 2, 810818, 2018.

Bond, G., Showers, W., Cheseby, M., Lotti, R., Almasi, P., DeMenocal, P., Priore, P., Cullen, H., Hajdas, I., and Bonani, G.: 370 A pervasive millennial-scale cycle in North Atlantic Holocene and glacial climates, Science, 278, 1257-1266, 1997.

Bond, G., Kromer, B., Beer, J., Muscheler, R., Evans, M. N., Showers, W., Hoffmann, S., Lotti-Bond, R., Hajdas, I., and Bonani, G.: Persistent solar influence on North Atlantic climate during the Holocene, Science, 294, 2130-2136, 2001.

Büntgen, U., Tegel, W., Nicolussi, K., McCormick, M., Frank, D., Trouet, V., Kaplan, J. O., Herzig, F., Heussner, K.-U., and Wanner, H.: 2500 years of European climate variability and human susceptibility, Science, 331, 578-582, 2011. 
https://doi.org/10.5194/cp-2020-98

Preprint. Discussion started: 7 August 2020

(c) Author(s) 2020. CC BY 4.0 License.

\section{(c) (1)}

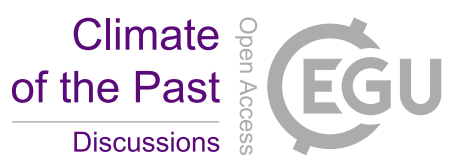

375 Caley, T., Roche, D. M., and Renssen, H.: Orbital Asian summer monsoon dynamics revealed using an isotope-enabled global climate model, Nat. Commun., 5, 5371, 2014.

Carolin, S. A., Walker, R. T., Day, C. C., Ersek, V., Sloan, R. A., Dee, M. W., Talebian, M., and Henderson, G. M.: Precise timing of abrupt increase in dust activity in the Middle East coincident with $4.2 \mathrm{ka}$ social change, P. Natl. Acad. Sci. USA, 116, 67-72, 2019.

380 Chen, F., Xu, Q., Chen, J., Birks, H. J. B., Liu, J., Zhang, S., Jin, L., An, C., Telford, R. J., and Cao, X.: East Asian summer monsoon precipitation variability since the last deglaciation, Sci. Rep., 5, 11186, 2015a.

Chen, J., Chen, F., Feng, S., Huang, W., Liu, J., and Zhou, A.: Hydroclimatic changes in China and surroundings during the Medieval Climate Anomaly and Little Ice Age: spatial patterns and possible mechanisms, Quaternary Sci. Rev., 107, 98-111, $2015 b$.

385 Cheng, H., Fleitmann, D., Edwards, R. L., Wang, X., Cruz, F. W., Auler, A. S., Mangini, A., Wang, Y., Kong, X., and Burns, S. J.: Timing and structure of the $8.2 \mathrm{kyr}$ BP event inferred from $\delta 18 \mathrm{O}$ records of stalagmites from China, Oman, and Brazil, Geology, 37, 1007-1010, 2009.

Cho, N.: Climate and drought: a new perspective on history, History and Discourse, 53, 607-619, 2009. (in Korean)

Chu, G., Sun, Q., Xie, M., Lin, Y., Shang, W., Zhu, Q., Shan, Y., Xu, D., Rioual, P., and Wang, L.: Holocene cyclic climatic

390 variations and the role of the Pacific Ocean as recorded in varved sediments from northeastern China, Quaternary Sci. Rev., 102, 85-95, 2014.

Conroy, J. L., Overpeck, J. T., Cole, J. E., Shanahan, T. M., and Steinitz-Kannan, M.: Holocene changes in eastern tropical Pacific climate inferred from a Galápagos lake sediment record, Quaternary Sci. Rev., 27, 1166-1180, 2008.

Constantine, M., Kim, M., and Park, J.: Mid-to late Holocene cooling events in the Korean Peninsula and their possible 395 impact on ancient societies, Quaternary Res., 92, 98-108, 2019.

Crema, E. R., Habu, J., Kobayashi, K., and Madella, M.: Summed probability distribution of 14C dates suggests regional divergences in the population dynamics of the Jomon period in eastern Japan, PLoS One, 11, e0154809, 2016.

Croudace, I. W., Rindby, A., and Rothwell, R. G.: ITRAX: description and evaluation of a new multi-function X-ray core scanner, Geological Society, London, Special Publications, 267, 51-63, 2006.

400 D'Andrea, W. J., Huang, Y., Fritz, S. C., and Anderson, N. J.: Abrupt Holocene climate change as an important factor for human migration in West Greenland, P. Natl. Acad. Sci. USA, 108, 9765-9769, 2011.

DeMenocal, P. B.: Cultural responses to climate change during the late Holocene, Science, 292, 667-673, 2001.

Demske, D., Tarasov, P. E., and Nakagawa, T.: Atlas of pollen, spores and further non-pollen palynomorphs recorded in the glacial-interglacial late Quaternary sediments of Lake Suigetsu, central Japan, Quatern. Int., 290, 164-238, 2013.

405 Dima, M., and Lohmann, G.: Conceptual model for millennial climate variability: a possible combined solar-thermohaline circulation origin for the 1,500-year cycle, Clim. Dynam., 32, 301-311, 2009.

Dixit, Y., Hodell, D. A., and Petrie, C. A.: Abrupt weakening of the summer monsoon in northwest India 4100 yr ago, Geology, 42, 339-342, 2014. 
https://doi.org/10.5194/cp-2020-98

Preprint. Discussion started: 7 August 2020

(c) Author(s) 2020. CC BY 4.0 License.

(c) (i)

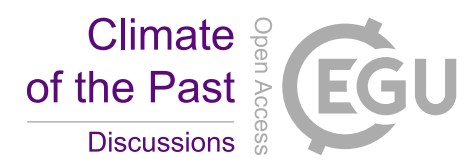

Dixit, Y., Hodell, D. A., Giesche, A., Tandon, S. K., Gázquez, F., Saini, H. S., Skinner, L. C., Mujtaba, S. A., Pawar, V., and

Singh, R. N.: Intensified summer monsoon and the urbanization of Indus Civilization in northwest India, Sci. Rep., 8, 1-8, 2018.

Donders, T. H., Wagner-Cremer, F., and Visscher, H.: Integration of proxy data and model scenarios for the mid-Holocene onset of modern ENSO variability, Quaternary Sci. Rev., 27, 571-579, 2008.

Dykoski, C. A., Edwards, R. L., Cheng, H., Yuan, D., Cai, Y., Zhang, M., Lin, Y., Qing, J., An, Z., and Revenaugh, J.: A

415 high-resolution, absolute-dated Holocene and deglacial Asian monsoon record from Dongge Cave, China, Earth Planet. Sc.

Lett., 233, 71-86, 2005.

Faegri, K., Kaland, P. E., and Krzywinski, K.: Textbook of pollen analysis, Ed. 4, John Wiley \& Sons Ltd., 1989.

Feng, J., and Hu, D.: How much does heat content of the western tropical Pacific Ocean modulate the South China Sea summer monsoon onset in the last four decades?, J. Geophys. Res.-Oceans, 119, 4029-4044, 2014.

420 Flohr, P., Fleitmann, D., Matthews, R., Matthews, W., and Black, S.: Evidence of resilience to past climate change in Southwest Asia: Early farming communities and the 9.2 and 8.2 ka events, Quaternary Sci. Rev., 136, 23-39, 2016.

Gamble, C., Davies, W., Pettitt, P., Hazelwood, L., and Richards, M.: The archaeological and genetic foundations of the European population during the Late Glacial: implications for 'agricultural thinking', Camb. Archaeol. J., 15, 193-223, 2005. Grimm, E.: Tilia and tiliagraph, Illinois State Museum, Springfield, 1991.

425 Grimm, E. C.: CONISS: a FORTRAN 77 program for stratigraphically constrained cluster analysis by the method of incremental sum of squares, Comput. Geosci., 13, 13-35, 1987.

Haug, G. H., Hughen, K. A., Sigman, D. M., Peterson, L. C., and Röhl, U.: Southward migration of the intertropical convergence zone through the Holocene, Science, 293, 1304-1308, 2001.

Hong, S., Woo, K., Yi, S., and Jo, K.-n.: Paleoclimatic reconstructions using textural data of the stalagmite from the Dangcheomul Cave, Jeju Island for the past 2,000 years, Journal of the Geological Society of Korea, 48, 445-458, 2012. (in Korean)

Hu, D., Wu, L., Cai, W., Gupta, A. S., Ganachaud, A., Qiu, B., Gordon, A. L., Lin, X., Chen, Z., and Hu, S.: Pacific western boundary currents and their roles in climate, Nature, 522, 299-308, 2015.

Ji, J., Shen, J., Balsam, W., Chen, J., Liu, L., and Liu, X.: Asian monsoon oscillations in the northeastern Qinghai-Tibet

435 Plateau since the late glacial as interpreted from visible reflectance of Qinghai Lake sediments, Earth Planet. Sc. Lett., 233, 61-70, 2005.

Jian, Z., Wang, P., Saito, Y., Wang, J., Pflaumann, U., Oba, T., and Cheng, X.: Holocene variability of the Kuroshio current in the Okinawa Trough, northwestern Pacific Ocean, Earth Planet. Sc. Lett., 184, 305-319, 2000.

Jo, K.-N., Yi, S., Lee, J.-Y., Woo, K. S., Cheng, H., Edwards, L. R., and Kim, S.-T.: 1000-year quasi-periodicity of weak monsoon events in temperate Northeast Asia since the mid-holocene, Sci. Rep., 7, 1-9, 2017. 
https://doi.org/10.5194/cp-2020-98

Preprint. Discussion started: 7 August 2020

(c) Author(s) 2020. CC BY 4.0 License.

(c) (i)

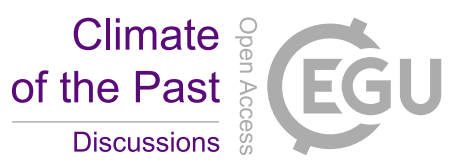

Kajita, H., Harada, N., Yokoyama, Y., Sato, M., Ogawa, N., Miyairi, Y., Sawada, C., Suzuki, A., and Kawahata, H.: High time-resolution alkenone paleotemperature variations in Tokyo Bay during the Meghalayan: Implications for cold climates and social unrest in Japan, Quaternary Sci. Rev., 230, 106160, 2020.

Kaniewski, D., Van Campo, E., and Weiss, H.: 3.2 Ka BP Megadrought and the Late Bronze Age Collapse, in: Megadrought and Collapse: From Early Agriculture to Angkor, edited by: Weiss, H., Oxford University Press, New York, United States of America, 161-182, 2017.

Kawahata, H., Yamamoto, H., Ohkushi, K. i., Yokoyama, Y., Kimoto, K., Ohshima, H., and Matsuzaki, H.: Changes of environments and human activity at the Sannai-Maruyama ruins in Japan during the mid-Holocene Hypsithermal climatic interval, Quaternary Sci. Rev., 28, 964-974, 2009.

450 Kim, J. C., and Bae, C. J.: Radiocarbon dates documenting the Neolithic-Bronze Age transition in Korea, Radiocarbon, 52, 483-492, 2010.

Korea National Insitute of Ecology: The 4th Natural Environment Survey 2015: Vegetation: Gyeongnam 1, 2016. (in Korean) Lachniet, M. S.: Climatic and environmental controls on speleothem oxygen-isotope values, Quaternary Sci. Rev., 28, 412432, 2009.

455 Lee, C.: Correlation of origins and chronology in Korean proto-historic archaeology, Journal of the Korean Archaeological Society, 102, 250-273, 2017. (in Korean)

Lee, E., Yi, S., Lim, J., Kim, Y., Jo, K.-n., and Kim, G. Y.: Multi-proxy records of Holocene hydroclimatic and environmental changes on the southern coast of South Korea, Palaeogeogr. Palaeocl., 545, 109642, 2020.

Lee, G.-A.: The transition from foraging to farming in prehistoric Korea, Curr. Anthropol., 52, S307-S329, 2011.

460 Li, C.-H., Li, Y.-X., Zheng, Y.-F., Yu, S.-Y., Tang, L.-Y., Li, B.-B., and Cui, Q.-Y.: A high-resolution pollen record from East China reveals large climate variability near the Northgrippian-Meghalayan boundary (around 4200 years ago) exerted societal influence, Palaeogeogr. Palaeocl., 512, 156-165, 2018.

Lim, J., and Fujiki, T.: Vegetation and climate variability in East Asia driven by low-latitude oceanic forcing during the middle to late Holocene, Quaternary Sci. Rev., 30, 2487-2497, 2011.

465 Löwemark, L., Chen, H.-F., Yang, T.-N., Kylander, M., Yu, E.-F., Hsu, Y.-W., Lee, T.-Q., Song, S.-R., and Jarvis, S.: Normalizing XRF-scanner data: a cautionary note on the interpretation of high-resolution records from organic-rich lakes, J. Asian Earth Sci., 40, 1250-1256, 2011.

Maher, B. A., and Thompson, R.: Oxygen isotopes from Chinese caves: records not of monsoon rainfall but of circulation regime, J. Quaternary Sci., 27, 615-624, 2012.

470 Manning, J. G., Ludlow, F., Stine, A. R., Boos, W. R., Sigl, M., and Marlon, J. R.: Volcanic suppression of Nile summer flooding triggers revolt and constrains interstate conflict in ancient Egypt, Nat. Commun., 8, 1-9, 2017.

McVean, D.: Alnus glutinosa (L.) Gaertn, J. Ecol., 41, 447-466, 1953.

Ministry of Environment of the Republic of Korea: National Survey on Natural Environments of Inland Wetlands 2001, 2002. (in Korean) 
https://doi.org/10.5194/cp-2020-98

Preprint. Discussion started: 7 August 2020

(c) Author(s) 2020. CC BY 4.0 License.

(c) (i)

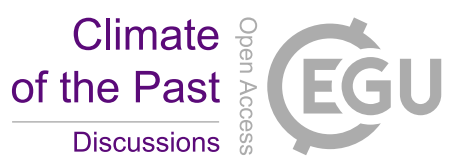

Moy, C. M., Seltzer, G. O., Rodbell, D. T., and Anderson, D. M.: Variability of El Niño/Southern Oscillation activity at millennial timescales during the Holocene epoch, Nature, 420, 162-165, 2002.

Munoz, S. E., Gajewski, K., and Peros, M. C.: Synchronous environmental and cultural change in the prehistory of the northeastern United States, P. Natl. Acad. Sci. USA, 107, 22008-22013, 2010.

Oh, Y., Conte, M., Kang, S., Kim, J., and Hwang, J.: Population fluctuation and the adoption of food production in prehistoric Korea: using radiocarbon dates as a proxy for population change, Radiocarbon, 59, 1761-1770, 2017.

Ólafsdóttir, K. B., Schulz, M., and Mudelsee, M.: REDFIT-X: Cross-spectral analysis of unevenly spaced paleoclimate time series, Comput. Geosci., 91, 11-18, 2016.

Park, J., Shin, Y. H., and Byrne, R.: Late-Holocene vegetation and climate change in Jeju Island, Korea and its implications for ENSO influences, Quaternary Sci. Rev., 153, 40-50, 2016.

485 Park, J.: Solar and tropical ocean forcing of late-Holocene climate change in coastal East Asia, Palaeogeogr. Palaeocl., 469, 74-83, 2017.

Park, J., Han, J., Jin, Q., Bahk, J., and Yi, S.: The link between ENSO-like forcing and hydroclimate variability of coastal East Asia during the last millennium, Sci. Rep., 7, 1-12, 2017.

Park, J., Park, J., Yi, S., Kim, J. C., Lee, E., and Jin, Q.: The 8.2 ka cooling event in coastal East Asia: High-resolution 490 pollen evidence from southwestern Korea, Sci. Rep., 8, 1-9, 2018.

Park, J., Park, J., Yi, S., Kim, J. C., Lee, E., and Choi, J.: Abrupt Holocene climate shifts in coastal East Asia, including the $8.2 \mathrm{ka}, 4.2 \mathrm{ka}$, and $2.8 \mathrm{ka}$ BP events, and societal responses on the Korean peninsula, Sci. Rep., 9, 1-16, 2019.

Reimer, P. J., Bard, E., Bayliss, A., Beck, J. W., Blackwell, P. G., Ramsey, C. B., Buck, C. E., Cheng, H., Edwards, R. L., and Friedrich, M.: IntCal13 and Marine13 radiocarbon age calibration curves 0-50,000 years cal BP, Radiocarbon, 55, 1869-

$4951887,2013$.

Renssen, H., Seppä, H., Heiri, O., Roche, D., Goosse, H., and Fichefet, T.: The spatial and temporal complexity of the Holocene thermal maximum, Nat. Geosci., 2, 411-414, 2009.

Renssen, H., Seppä, H., Crosta, X., Goosse, H., and Roche, D. M.: Global characterization of the Holocene thermal maximum, Quaternary Sci. Rev., 48, 7-19, 2012.

500 Roffet-Salque, M., Marciniak, A., Valdes, P. J., Pawłowska, K., Pyzel, J., Czerniak, L., Krüger, M., Roberts, C. N., Pitter, S., and Evershed, R. P.: Evidence for the impact of the 8.2-kyBP climate event on Near Eastern early farmers, P. Natl. Acad. Sci. USA, 115, 8705-8709, 2018.

Roth, S., and Reijmer, J. J.: Holocene millennial to centennial carbonate cyclicity recorded in slope sediments of the Great Bahama Bank and its climatic implications, Sedimentology, 52, 161-181, 2005.

505 Ryan, W. B., Carbotte, S. M., Coplan, J. O., O'Hara, S., Melkonian, A., Arko, R., Weissel, R. A., Ferrini, V., Goodwillie, A., and Nitsche, F.: Global multi-resolution topography synthesis, Geochem. Geophy. Geosy., 10, 2009.

Scuderi, L. A.: A 2000-year tree ring record of annual temperatures in the Sierra Nevada mountains, Science, 259, 14331436, 1993. 
https://doi.org/10.5194/cp-2020-98

Preprint. Discussion started: 7 August 2020

(c) Author(s) 2020. CC BY 4.0 License.

\section{(c) (i)}

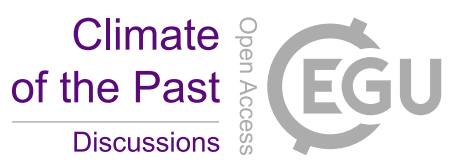

Seppä, H., and Bennett, K. D.: Quaternary pollen analysis: recent progress in palaeoecology and palaeoclimatology, Prog.

Phys. Geog., 27, 548-579, 2003.

Stebich, M., Rehfeld, K., Schluetz, F., Tarasov, P. E., Liu, J., and Mingram, J.: Holocene vegetation and climate dynamics of NE China based on the pollen record from Sihailongwan Maar Lake, Quaternary Sci. Rev., 124, 275-289, 2015.

Steinhilber, F., Beer, J., and Fröhlich, C.: Total solar irradiance during the Holocene, Geophys. Res. Lett., 36, 2009.

Stott, L., Cannariato, K., Thunell, R., Haug, G. H., Koutavas, A., and Lund, S.: Decline of surface temperature and salinity in

the western tropical Pacific Ocean in the Holocene epoch, Nature, 431, 56-59, 2004.

Sun, Y., Oppo, D. W., Xiang, R., Liu, W., and Gao, S.: Last deglaciation in the Okinawa Trough: Subtropical northwest Pacific link to Northern Hemisphere and tropical climate, Paleoceanography, 20, 2005.

Sun, Y., Wu, F., Clemens, S. C., and Oppo, D. W.: Processes controlling the geochemical composition of the South China Sea sediments during the last climatic cycle, Chem. Geol., 257, 240-246, 2008.

Surovell, T. A., Finley, J. B., Smith, G. M., Brantingham, P. J., and Kelly, R.: Correcting temporal frequency distributions for taphonomic bias, J. Archaeol. Sci., 36, 1715-1724, 2009.

Tallavaara, M., Luoto, M., Korhonen, N., Järvinen, H., and Seppä, H.: Human population dynamics in Europe over the Last Glacial Maximum, P. Natl. Acad. Sci. USA, 112, 8232-8237, 2015.

Timmermann, A., An, S.-I., Kug, J.-S., Jin, F.-F., Cai, W., Capotondi, A., Cobb, K. M., Lengaigne, M., McPhaden, M. J., and Stuecker, M. F.: El Niño-southern oscillation complexity, Nature, 559, 535-545, 2018.

Veski, S., Seppä, H., and Ojala, A. E.: Cold event at 8200 yr BP recorded in annually laminated lake sediments in eastern Europe, Geology, 32, 681-684, 2004.

Wang, C., Lu, H., Zhang, J., Gu, Z., and He, K.: Prehistoric demographic fluctuations in China inferred from radiocarbon data and their linkage with climate change over the past 50,000 years, Quaternary Sci. Rev., 98, 45-59, 2014.

530 Wang, Y., Cheng, H., Edwards, R. L., He, Y., Kong, X., An, Z., Wu, J., Kelly, M. J., Dykoski, C. A., and Li, X.: The Holocene Asian monsoon: links to solar changes and North Atlantic climate, Science, 308, 854-857, 2005.

Wanner, H., Beer, J., Bütikofer, J., Crowley, T. J., Cubasch, U., Flückiger, J., Goosse, H., Grosjean, M., Joos, F., and Kaplan, J. O.: Mid-to Late Holocene climate change: an overview, Quaternary Sci. Rev., 27, 1791-1828, 2008.

Wanner, H., Solomina, O., Grosjean, M., Ritz, S. P., and Jetel, M.: Structure and origin of Holocene cold events, Quaternary 535 Sci. Rev., 30, 3109-3123, 2011.

Weiss, H., Courty, M.-A., Wetterstrom, W., Guichard, F., Senior, L., Meadow, R., and Curnow, A.: The genesis and collapse of third millennium north Mesopotamian civilization, Science, 261, 995-1004, 1993.

Weng, C., Bush, M. B., and Chepstow-Lusty, A. J.: Holocene changes of Andean alder (Alnus acuminata) in highland Ecuador and Peru, J. Quaternary Sci., 19, 685-691, 2004.

540 Woodbridge, J., Roberts, C. N., Palmisano, A., Bevan, A., Shennan, S., Fyfe, R., Eastwood, W. J., Izdebski, A., Çakırlar, C., and Woldring, H.: Pollen-inferred regional vegetation patterns and demographic change in Southern Anatolia through the Holocene, Holocene, 29, 728-741, 2019. 
https://doi.org/10.5194/cp-2020-98

Preprint. Discussion started: 7 August 2020

(c) Author(s) 2020. CC BY 4.0 License.

(c) (i)

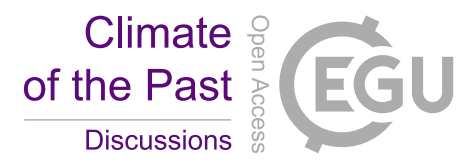

Xiao, J., Xu, Q., Nakamura, T., Yang, X., Liang, W., and Inouchi, Y.: Holocene vegetation variation in the Daihai Lake region of north-central China: a direct indication of the Asian monsoon climatic history, Quaternary Sci. Rev., 23, 16691679, 2004.

Xiao, J., Zhang, S., Fan, J., Wen, R., Zhai, D., Tian, Z., and Jiang, D.: The 4.2 ka BP event: multi-proxy records from a closed lake in the northern margin of the East Asian summer monsoon, Clim. Past., 14, 1417-1425, 2018.

Xie, S., Evershed, R. P., Huang, X., Zhu, Z., Pancost, R. D., Meyers, P. A., Gong, L., Hu, C., Huang, J., and Zhang, S.: Concordant monsoon-driven postglacial hydrological changes in peat and stalagmite records and their impacts on prehistoric cultures in central China, Geology, 41, 827-830, 2013.

Xu, D., Lu, H., Chu, G., Wu, N., Shen, C., Wang, C., and Mao, L.: 500-year climate cycles stacking of recent centennial warming documented in an East Asian pollen record, Sci. Rep., 4, 3611, 2014.

Xu, D., Lu, H., Chu, G., Liu, L., Shen, C., Li, F., Wang, C., and Wu, N.: Synchronous 500-year oscillations of monsoon climate and human activity in Northeast Asia, Nat. Commun., 10, 1-10, 2019.

555 Yang, S., Ding, Z., Li, Y., Wang, X., Jiang, W., and Huang, X.: Warming-induced northwestward migration of the East Asian monsoon rain belt from the Last Glacial Maximum to the mid-Holocene, P. Natl. Acad. Sci. USA, 112, 13178-13183, 2015.

Yoon, S.-O., KIm, H., Hwang, S., and Choi, J.: Environmental Change and Agricultural Activities during the Late Holocene in Geumcheon-ri, Milyang City, Korea, Journal of the Korean Archaeological Society, 56, 27-48, 2005. (in Korean)

560 Yu, K. B., Kong, D., Lee, H., Kim, C., and Lim, J.: Asian Monsoon Variation revealed by the speleothem records from Pyeongchang, Korea, Journal of the Korean association of regional geographers, 22, 439-449, 2016. (in Korean)

Zhou, T., Gong, D., Li, J., and Li, B.: Detecting and understanding the multi-decadal variability of the East Asian Summer Monsoon-Recent progress and state of affairs, Meteorol. Z., 18, 455-467, 2009.

Zhou, X., Sun, L., Zhan, T., Huang, W., Zhou, X., Hao, Q., Wang, Y., He, X., Zhao, C., and Zhang, J.: Time-transgressive onset of the Holocene Optimum in the East Asian monsoon region, Earth Planet. Sc. Lett., 456, 39-46, 2016.

Zhu, Z., Feinberg, J. M., Xie, S., Bourne, M. D., Huang, C., Hu, C., and Cheng, H.: Holocene ENSO-related cyclic storms recorded by magnetic minerals in speleothems of central China, P. Natl. Acad. Sci. USA, 114, 852-857, 2017. 




Figure 1: (a) Locations of the STP18-03 core (yellow star, this study) and other proxies mentioned in this article (white squares): A7 from Okinawa Trough (Sun et al., 2005), MD98-2176 from the Arafura Sea (Stott et al., 2004), Lake Xiaolongwan (Chu et al., 2014; Xu et al., 2019; Xu et al., 2014), Lake Sihailongwan (Stebich et al., 2015), Daihai Lake (Xiao et al., 2004), Gonghai Lake (Chen et al., 2015a), Qinghai Lake (Ji et al., 2005), and Dongge Cave (Wang et al., 2005; Dykoski et al., 2005). Red arrows indicate the trajectory of the Kuroshio Current. Blue arrows indicate the trajectories of the East Asian Summer Monsoon (EASM) and Indian Summer Monsoon (ISM). (b) Map of the Korean Peninsula, showing the locations of GY-1 (Park et al., 2019), Pomaeho Lake (Constantine et al., 2019), and Jeju Island (Park, 2017). The maps in (a) and (b) were produced using the GMRT tool (Ryan et al., 2009). (c) Regional satellite map of our coring site (yellow star), showing the locations of the Jongnamsan (663 m) and Palbongsan (391 m) mountains and the Miryang River. This map was adapted from the (C) Google Earth Pro software ver. 7.3.3.7673 (https://earth.google.com/). (d) Mean monthly temperature and precipitation in Miryang during 1981-2010 (Korea Meteorological Administration, 2020). 
https://doi.org/10.5194/cp-2020-98

Preprint. Discussion started: 7 August 2020

(c) Author(s) 2020. CC BY 4.0 License.

(c) (i)
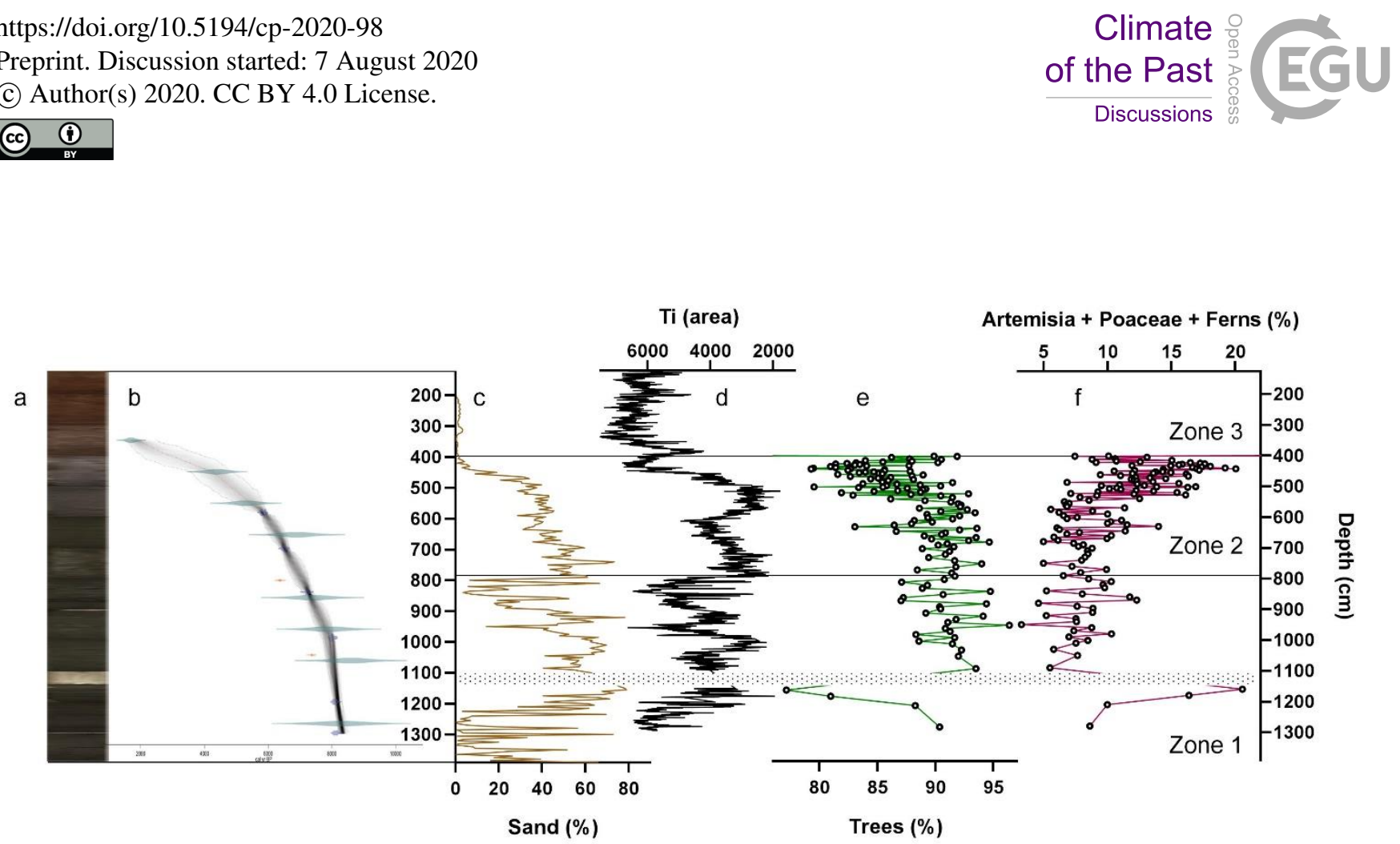

Figure 2: (a) Digital image of the STP18-03 core and (b) age-depth model constructed using the R bacon package ver. 2.3 (Blaauw and Christen, 2011) with the IntCal13 calibration dataset (Reimer et al., 2013). Samples omitted from the chronology model are indicated in red. (c-f) results of multi-proxy analyses of (c) sand proportion, brown; (d) titanium (Ti) content, black; (e) tree pollen percentage, green; and (f) sum of Artemisia (mugwort) and Poaceae (wild grass) pollen and fern spores, magenta. Zones are separated by black horizontal lines. 
https://doi.org/10.5194/cp-2020-98

Preprint. Discussion started: 7 August 2020

(c) Author(s) 2020. CC BY 4.0 License.

(c) (i)
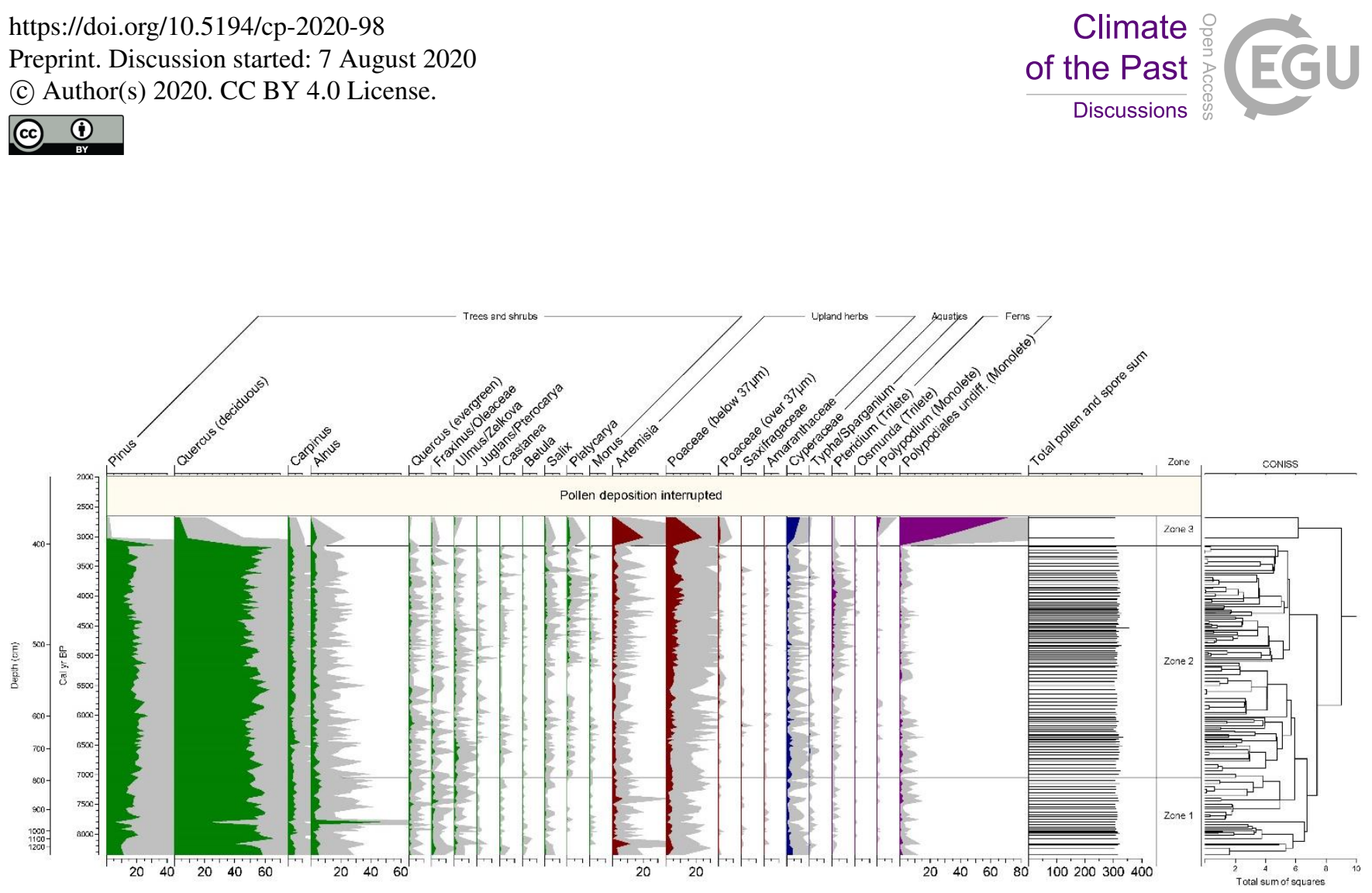

Figure 3: STP18-03 pollen diagram of selected taxa. All pollen percentages were calculated based on the sum of all terrestrial pollen and spores. 


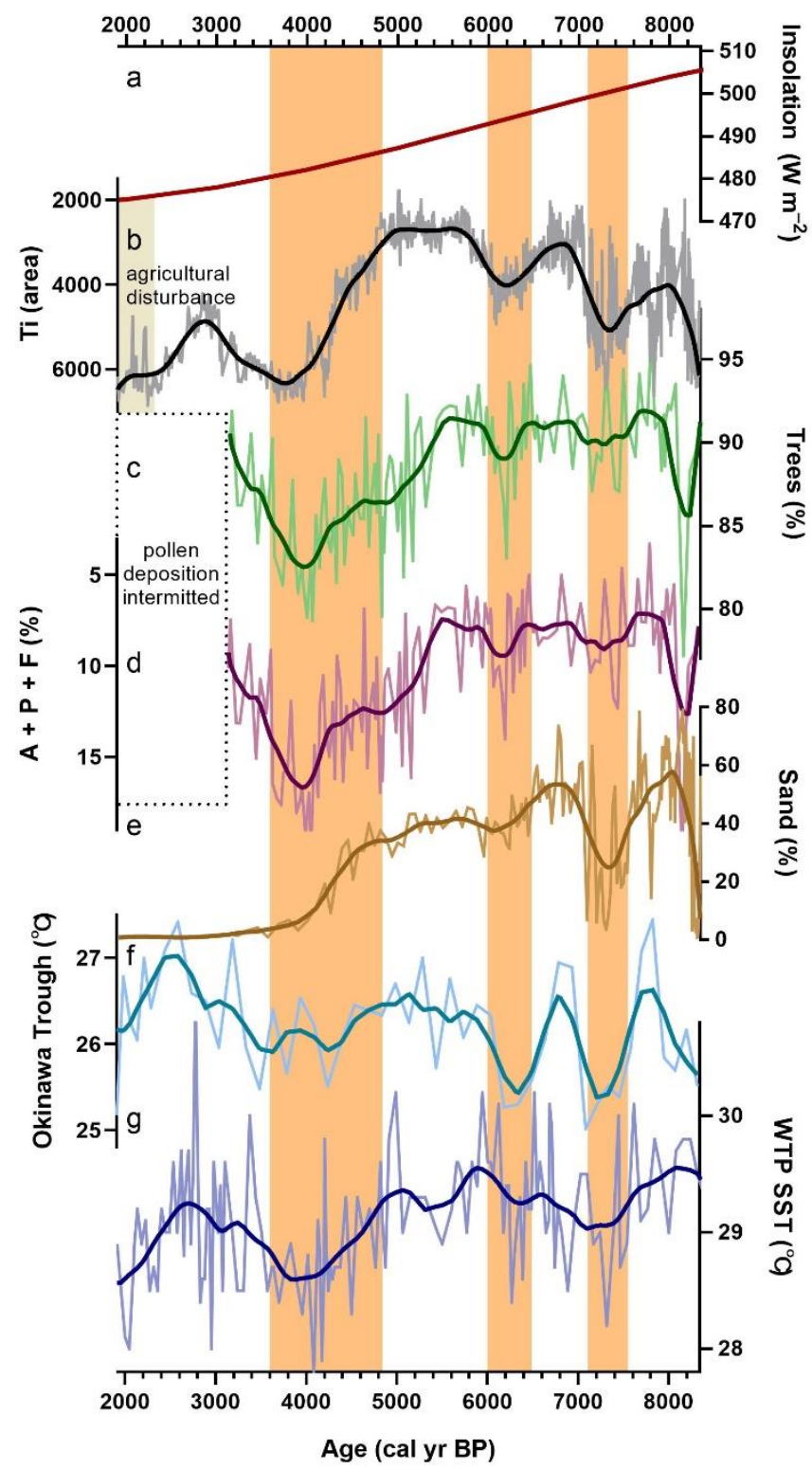

595 Figure 4: Comparison of results for paleoclimate proxies. (a) June insolation curve at $30^{\circ} \mathrm{N}$, red (Berger and Loutre, 1991); (b) titanium content, black (this study); (c) tree pollen percentage in Miryang, green (this study); (d) sum of Artemisia (mugwort) and Poaceae (wild grass) pollen and fern spores, magenta (this study); (e) sand proportion over $63 \mu \mathrm{m}$ in diameter, brown (this study); (f) sea surface temperature (SST) records from the A7 core, Okinawa Trough (Sun et al., 2005) (Fig. 1a), cyan; and (g) SST records from MD98-2176, Western Tropical Pacific (Stott et al., 2004) (Fig. 1a), blue. Smoothed lines in (b-g) were calculated using locally weighted scatterplot smoothing (LOWESS) regressions with 20-point windows. Vertical orange boxes indicate periods of drier climate. Box with black dotted edges indicates a zone with intermittent pollen deposition. Brown shading indicates an estimated period of agricultural disturbance following Yoon et al. (2005). 
https://doi.org/10.5194/cp-2020-98

Preprint. Discussion started: 7 August 2020

(c) Author(s) 2020. CC BY 4.0 License.

(c) (i)
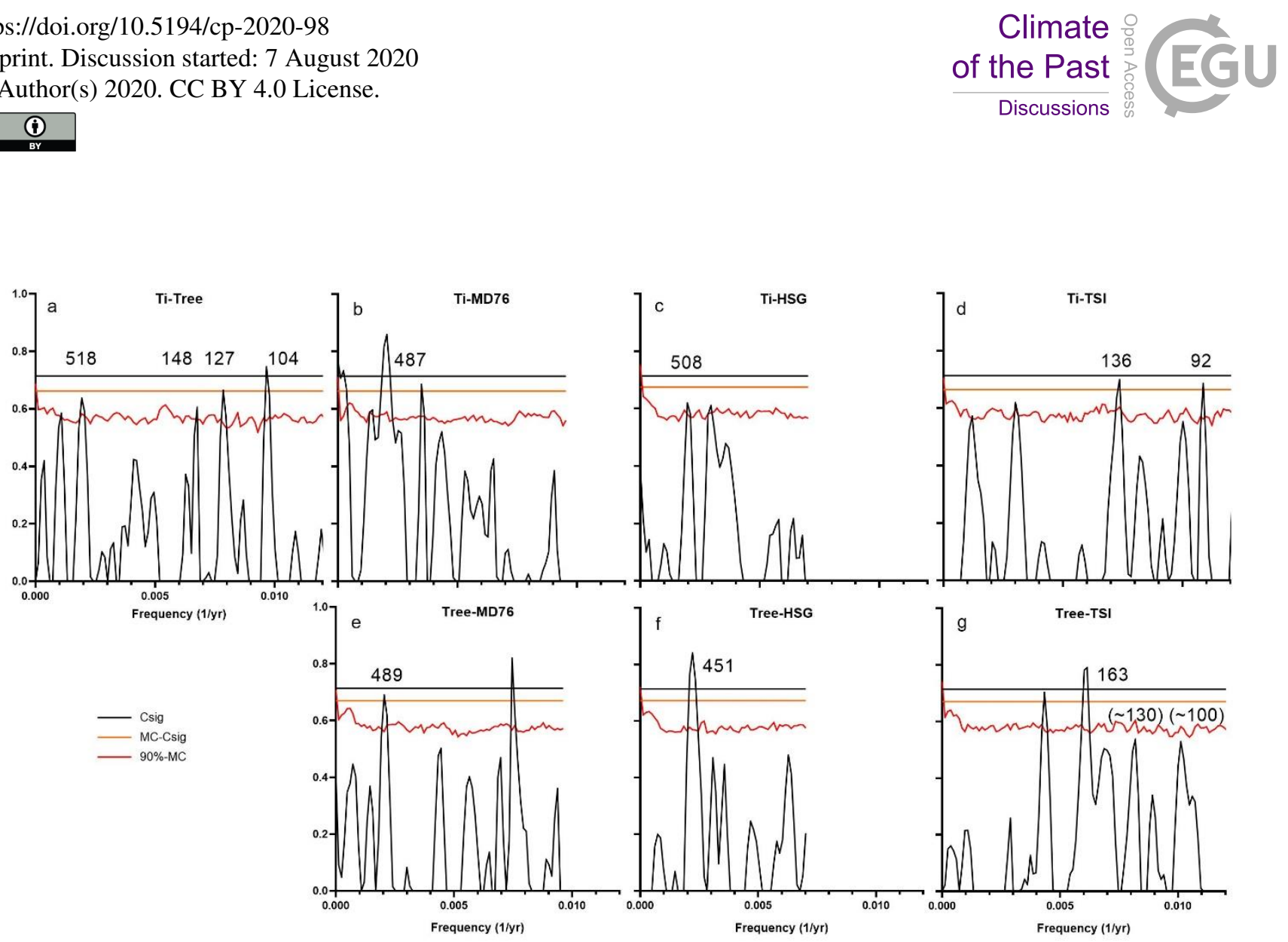

605 Figure 5: Coherency spectra for (a) titanium - tree percentage, (b) titanium - MD76 (Stott et al., 2004), (c) titanium - hematitestained grains (HSG) (Bond et al., 2001), (d) titanium - total solar irradiation (TSI) (Steinhilber et al., 2009), (e) tree - MD76, (f) tree - HSG, and (g) tree - TSI. Theoretical, mean Monte Carlo (for alpha $=\mathbf{0 . 0 5 0}$ ), and $90 \%$ Monte Carlo false alarm levels are indicated by black, orange, and red lines, respectively. All cross-spectral analyses were conducted using the REDFIT-X software ver. 1.1 (Ólafsdóttir et al., 2016). 


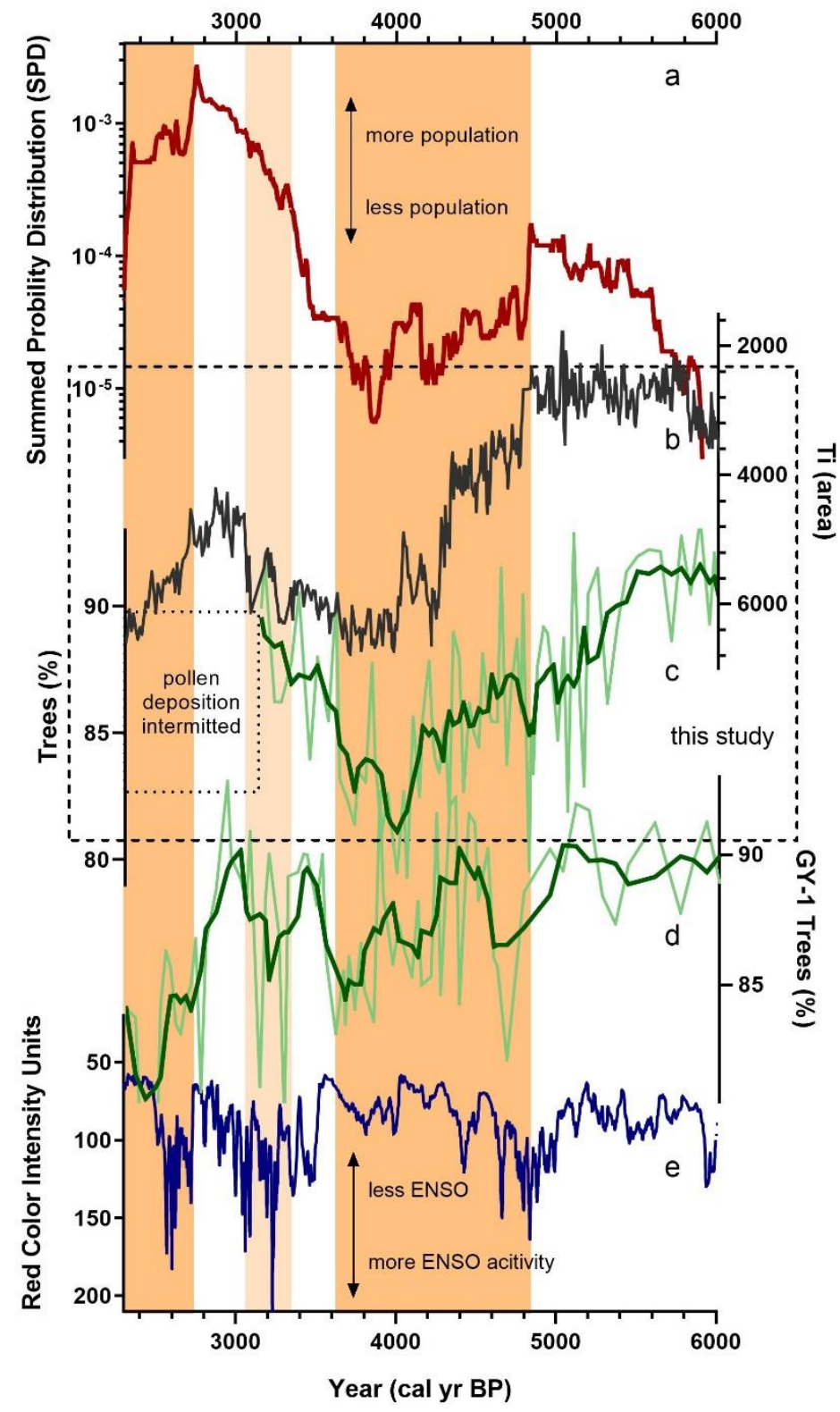

Figure 6: Comparison of the results of paleoclimate proxies and past human activity indicators. (a) Normalized summed probability distribution (SPD) values on archaeological records found in the Korean Peninsula, red (Oh et al., 2017); (b) titanium content in STP18-03, black (this study); and (c) tree pollen percentages from STP18-03, green (this study) and (d) GY-1, green (Park et al., 2019) (Fig. 1b); and (e) red color intensity units from Laguna Pallcacocha, an indicator of El Niño-Southern Oscillation (ENSO), blue (Moy et al., 2002). Vertical orange boxes indicate periods of drier climate and lower population. Raw values were smoothed in (c) and (d) by 5-point means and in (e) by 31-point means. 
https://doi.org/10.5194/cp-2020-98

Preprint. Discussion started: 7 August 2020

(c) Author(s) 2020. CC BY 4.0 License.

Climate

(c) (1)

Discussions

\begin{tabular}{|c|c|c|c|c|c|}
\hline OSL sample depth (m) & Dose rate $(\mathrm{Gy} / \mathrm{ka})$ & \multicolumn{2}{|c|}{ Water content $(\%)$} & Equivalent dose (Gy) & OSL age (yr BP) \\
\hline $3.50-3.55$ & $2.94 \pm 0.20$ & \multicolumn{2}{|c|}{28.3} & $5.09 \pm 0.20$ & $1700 \pm 130$ \\
\hline $4.50-4.55$ & $3.23 \pm 0.20$ & \multicolumn{2}{|c|}{37.4} & $14.09 \pm 0.19$ & $4400 \pm 270$ \\
\hline $5.50-5.55$ & $3.55 \pm 0.20$ & \multicolumn{2}{|c|}{26.8} & $18.75 \pm 0.40$ & $5300 \pm 320$ \\
\hline $6.50-6.55$ & $3.21 \pm 0.18$ & \multicolumn{2}{|c|}{33.3} & $22.14 \pm 0.58$ & $6900 \pm 430$ \\
\hline $8.50-8.55$ & $3.21 \pm 0.20$ & \multicolumn{2}{|c|}{39.1} & $23.88 \pm 0.20$ & $7400 \pm 460$ \\
\hline $9.50-9.55$ & $3.08 \pm 0.17$ & \multicolumn{2}{|c|}{40.0} & $24.32 \pm 0.45$ & $7900 \pm 470$ \\
\hline $10.50-10.55$ & $3.39 \pm 0.19$ & \multicolumn{2}{|c|}{30.6} & $29.28 \pm 0.48$ & $8600 \pm 500$ \\
\hline $12.50-12.55$ & $3.02 \pm 0.19$ & \multicolumn{2}{|c|}{40.0} & $25.25 \pm 0.99$ & $8300 \pm 620$ \\
\hline AMS sample depth (m) & Material dated & Lab code & $\delta 13 \mathrm{C}(\%)$ & Age $\left({ }^{14} \mathrm{C}\right.$ yr BP $)$ & Calibrated age (yr BP) \\
\hline 5.80 & Plant fragments & KGM-ITg190725 & -28.8 & $5110 \pm 40$ & $5840 \pm 90$ \\
\hline 6.94 & Plant fragments & KGM-ITg190726 & -27.7 & $5710 \pm 40$ & $6520 \pm 110$ \\
\hline $7.95^{\mathrm{a}}$ & Plant fragments & KGM-ITg190727 & -32.5 & $5570 \pm 50$ & $6360 \pm 80$ \\
\hline 8.32 & Plant fragments & KGM-ITg190728 & -32.0 & $6310 \pm 40$ & $7240 \pm 80$ \\
\hline 9.77 & Plant fragments & KGM-ITg190729 & -33.9 & $7210 \pm 40$ & $8060 \pm 100$ \\
\hline $10.32^{\mathrm{a}}$ & Plant fragments & KGM-ITg190730 & -30.8 & $6500 \pm 50$ & $7430 \pm 120$ \\
\hline 11.81 & Plant fragments & KGM-ITg190731 & -30.8 & $7280 \pm 40$ & $8090 \pm 80$ \\
\hline 12.80 & Plant fragments & KGM-ITg190732 & -27.1 & $7330 \pm 50$ & $8160 \pm 140$ \\
\hline
\end{tabular}

Table 1: Radiocarbon and optically stimulated luminescence (OSL) dating results for the STP18-03 core.

a Excluded from the age model. 
https://doi.org/10.5194/cp-2020-98

Preprint. Discussion started: 7 August 2020

(C) Author(s) 2020. CC BY 4.0 License.

(c) (i)

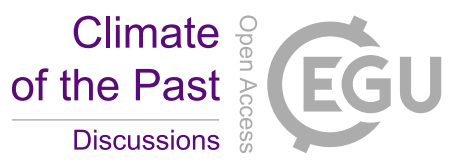

The English in this document has been checked by at least two professional editors, both native speakers of English. For a certificate, please see:

625

http://www.textcheck.com/certificate/PSeujQ 